\section{Evaluation of Shallow Subsurface Drip Irrigation for the Production of Acorn Squash}

\author{
Timothy Coolong ${ }^{1}$
}

\begin{abstract}
AdDitional INDEX wORDs. automated irrigation, Cucurbita pepo, SDI, soil moisture, tensiometer, WUE

SUMmARY. Subsurface drip irrigation (SDI) has been increasingly used for the production of numerous agronomic crops and a limited number of vegetable crops. To determine the impact of SDI compared with surface drip irrigation (SUR), a study was conducted in 2011 and 2012 with 'Table Queen' acorn squash (Cucurbita pepo var. turbinata) with irrigation initiated at $75 \%$ and $50 \%$ plant available water (PAW). The study was arranged as a factorial randomized complete block design and plants were grown with two irrigation types (SUR or SDI) and two tensiometer-controlled irrigation regimes. Results from 2011 suggested that SDI used less water compared with SUR at each irrigation set point. However, in 2012, significantly more water was used in all treatments due to warmer temperatures and less rainfall. In 2012, SDI used more water than SUR treatments at the same irrigation set point. In 2012, yield was affected by irrigation treatment. Plants grown using SUR irrigating at $75 \%$ PAW had greater numbers of fruit compared with other treatments. Furthermore, the highest yielding treatment had more than twice the number of irrigation events than the other treatments though the average lengths of irrigation events were shorter. Although overall yields were greater in 2012 , irrigation water use efficiency (iWUE) was lower than in 2011 due to increased water use. These results suggest that while SDI may have some advantages over traditional SUR, environmental factors during growth can significantly impact the efficiency and productivity of each system.
\end{abstract}

S ubsurface drip irrigation has been increasingly employed for the production of specific vegetables, such as onion (Allium cepa) and processing tomato (Solanum lycopersicum) (Ayars et al., 2015; Enciso et al., 2007; Leskovar et al., 2004). Subsurface drip irrigation has been reported to increase yields and iWUE for processing tomato compared with SUR (Ayars et al., 1999, 2015). In addition, SDI may increase nutrient use efficiency (Zotarelli et al., 2008), improve pesticide and fumigant placement in plant beds (Camp, 1998; Lamm and Camp, 2007; Woodrow et al., 2008), and reduce soil surface wetting, thus reducing weed pressure, particularly in arid climates (Coolong, 2013).

Traditional SDI systems are intended to be semipermanent installations with rigid polyvinyl chloride (PVC) mainlines connected to flexible drip-tape laterals placed 15 to 20 inches below the soil surface. Irrigation at these depths is well suited for deep-rooted agronomic crops such as field corn (Zea mays) and cotton

Department of Horticulture, University of Georgia, 2360 Rainwater Road, Tifton, GA 31793

${ }^{1}$ Corresponding author. E-mail: tcoolong@uga.edu.
(Gossypium sp.) (Lamm and Camp, $2007)$. In processing tomato, SDI has successfully been used at depths of 18 inches (Ayars et al., 2015). However, due to the shallow-rooted nature of many vegetables, SDI laterals for these crops are often located at depths of 6 to 12 inches (Lamm and Camp, 2007). Although drip tubing placed at depths of 12 inches may be intended for long-term applications, shallower tubing is often meant to be in place for one or two seasons. Shallow SDI systems can be deployed using an array of implements, from bed shapers/mulch layers to specially designed drip tape layers for placement of drip tubing in row. Most systems use flexible PVC or polyethylene hoses for mainlines as would be done with SUR.

Zotarelli et al. (2008) reported significantly increased yields in zucchini squash (C. pepo var. cylindrica) resulting from improved nitrogen use efficiency with drip tubing placed $15 \mathrm{~cm}$ below the surface of a plastic mulch beds. Placing SDI at depths of $20 \mathrm{~cm}$ has been reported to increase root density in bell pepper (Capsicum annuиm) due to an increase in root growth near emitters (Kong et al., 2012). Leskovar et al. (2001) noted a significant improvement in the yield of cantaloupe (Cucumis melo) when grown with SDI at $10-\mathrm{cm}$ depths compared with SUR and SDI at $30-\mathrm{cm}$ depths. Shallow SDI that is intended for annual use can also help reduce surface wetting and subsequent weed growth in vegetable production systems. Significant reductions in weed growth have been documented in tomato production when SDI laterals were placed at depths of $25 \mathrm{~cm}$ (Grattan et al., 1988) compared with furrow irrigation. Patel and Rajput (2007) documented a reduction in weed pressure in potato (Solanum tuberosum) with SDI placed at depths as shallow as $10 \mathrm{~cm}$ below the soil surface; however, surface wetting and weed pressure were present when SDI was placed at $5-\mathrm{cm}$ depths. Organic vegetable producers are also using shallow SDI to reduce surface wetting, reducing weed pressure, and allowing for cultivation without disturbing drip tubing (Coolong, 2013).

Although SDI has been reported to increase yields, reduce water use, and increase nutrient use efficiencies

\begin{tabular}{llll}
\hline $\begin{array}{l}\text { Units } \\
\begin{array}{l}\text { To convert U.S. to SI, } \\
\text { multiply by }\end{array}\end{array}$ & U.S. unit & SI unit & $\begin{array}{l}\text { To convert SI to U.S., } \\
\text { multiply by }\end{array}$ \\
\hline 0.4047 & acre $(\mathrm{s})$ & $\mathrm{ha}$ & 2.4711 \\
1 & $\mathrm{cbar}$ & $\mathrm{kPa}$ & $\mathrm{l}$ \\
73.0778 & $\mathrm{fl} \mathrm{oz} / \mathrm{acre}$ & $\mathrm{mL} \cdot \mathrm{ha}^{-1}$ & 0.0137 \\
0.3048 & $\mathrm{ft}$ & $\mathrm{m}$ & 3.2808 \\
9.3540 & $\mathrm{gal} / \mathrm{acre}$ & $\mathrm{L} \cdot \mathrm{ha}^{-1}$ & 0.1069 \\
2.54 & inch $(\mathrm{es})$ & $\mathrm{cm}$ & 0.3937 \\
1.1209 & $\mathrm{lb} / \mathrm{acre}$ & $\mathrm{kg} \cdot \mathrm{ha}^{-1}$ & 0.8922 \\
0.1198 & $\mathrm{lb} / \mathrm{gal}$ & $\mathrm{kg} \cdot \mathrm{L}^{-1}$ & 8.3454 \\
0.0254 & $\mathrm{mil}$ & $\mathrm{mm}$ & 39.3701 \\
28.3495 & $\mathrm{oz}$ & $\mathrm{g}$ & 0.0353 \\
70.0532 & $\mathrm{oz} / \mathrm{acre}$ & $\mathrm{g} \cdot \mathrm{ha} \mathrm{C}^{-1}$ & 0.0143 \\
1 & $\mathrm{ppm}$ & $\mathrm{mg} \cdot \mathrm{L}^{-1}$ & 1 \\
6.8948 & $\mathrm{psi}$ & $\mathrm{kPa}$ & 0.1450 \\
$\left({ }^{\circ} \mathrm{F}-32\right) \div 1.8$ & ${ }^{\circ} \mathrm{F}$ & ${ }^{\circ} \mathrm{C}$ & $\left({ }^{\circ} \mathrm{C} \times 1.8\right)+32$
\end{tabular}


(Lamm and Camp, 2007), there are some limitations that require consideration. Clogged emitters or cuts in the line may go unnoticed for long periods of time. Furthermore, due to limited surface wetting, it can be challenging to germinate direct-seeded crops and provide sufficient amounts of water to vegetable transplants. Capillary water movement from SDI upward into the root zone can be limited on sandy soils. In addition, there may be differences regarding the management of SDI compared with SUR in vegetable production systems. Zotarelli et al. (2009) reported that SDI used more water than SUR when both systems were controlled by soil moisture sensors with the same set points. This resulted in a lower iWUE for SDI compared with SUR. Differences between these systems regarding irrigation tape placement relative to soil moisture sensors may have contributed to the greater water use in the SDI system. Dabach and Lazarovith (2015) reported that optimal placement for tensiometers for controlling high-frequency (pulsed) irrigation in a shallow ( $15-\mathrm{cm}$ depth) SDI system should be in close proximity $(<10 \mathrm{~cm})$ to drip emitters; and when tensiometers were $20 \mathrm{~cm}$ or more from emitters, drainage below the estimated root zone increased. However, previous reports for tensiometer-based irrigation using surface drip tubing have used tensiometers placed equidistant between plants in a row. Tensiometers were typically placed in the planted row or midway between drip tubing and the planted row at depths of 6 inches (Coolong et al., 2011b; Smajstrla and Locascio, 1996). This suggests that while SDI that is managed with a soil moisturebased system may be more efficient than a time-based system (Zotarelli et al., 2008, 2009), there are likely key differences in how SUR and SDI respond to irrigation management.

The objectives of the present study were to determine how drip tape placement (SUR and SDI) and irrigation regime would impact water use and productivity of a vegetable crop grown on a bare ground production system. Acorn squash was chosen as it is a deep-rooted vegetable crop (Maynard and Hochmuth, 2007), and there is little published data regarding the use of SDI in the field for the production of long-season cucurbit crops such as hard squashes (Cucurbita sp.) and pumpkins (C. pepo var. pepo). In addition, acorn squash is typically grown in bare ground plantings, where the weed control benefits of SDI may be observed.

\section{Materials and methods}

This trial was conducted at the University of Kentucky Horticulture Research Farm in Lexington (lat. $38^{\circ} 3^{\prime} \mathrm{N}$, long. $84^{\circ} 30^{\prime} \mathrm{W}$ ) in $201 \mathrm{l}$ and 2012 . The soil was a Maury silt loam series ( $0 \%$ to $2 \%$ slope $)$, which is a fine, mixed, mesic Typic Alfisol. Seed of 'Table Queen' acorn squash (Seedway, Hall, NY) were planted into 128-cell greenhouse trays filled with soilless media (Pro-Mix BX; Premier Tech, Riviere-du-Loup, QC, Canada) on 9 June 2011 and 24 May 2012. An earlier planting date was chosen in 2012 to reduce the potential for disease pressure late in the study. Seedlings were greenhouse grown at temperature set points of $86 / 76{ }^{\circ} \mathrm{F}$ (day/night). Plants were watered daily as needed and fertilized weekly with a $150 \mathrm{mg} \cdot \mathrm{L}^{-1}$ nitrogen $(\mathrm{N})$ solution $(20 \mathrm{~N}-4.4 \mathrm{P}-16.6 \mathrm{~K}$; Scotts, Marysville, $\mathrm{OH})$. On 16 July 2011 and 20 June 2012, seedlings were planted by hand into 6- to 7 -inch-tall raised beds formed using a bed shaper (model 2550; Rain-Flo Irrigation, East Earl, PA). Raised beds were $\approx 28$ inches wide and $\approx 5$ to 6 inches in height. Single lines of drip irrigation tubing [12-inch emitter spacing, $0.45 \mathrm{gal} / \mathrm{min}$ per $100 \mathrm{ft}$, 10-mil (Aqua-Traxx; Toro, El Cajon, $\mathrm{CA})]$ were placed in the center of each bed at a depth of 6 inches at the time of bed formation. Beds were spaced on 6 - $\mathrm{ft}$ centers and transplants were placed in the center of each bed with 24-inch within-row spacing resulting in a population of 3630 plants/acre

In both years, $75 \mathrm{lb} /$ acre $\mathrm{N}$ (19N-8.3P-15.8K; Southern States Cooperative, Lexington, KY) were incorporated in the soil during bed formation. Plants received an additional $50 \mathrm{lb} /$ acre $\mathrm{N}(15.5 \mathrm{~N}-0 \mathrm{P}-0 \mathrm{~K}$ calcium nitrate; Southern States Cooperative) in five applications of $10 \mathrm{lb} /$ acre $\mathrm{N} /$ week through the drip irrigation beginning $\approx 10 \mathrm{~d}$ after transplanting. The insecticide, imidacloprid [4.49 fl oz/acre a.i. (Admire Pro; Bayer Crop Science, Research Triangle Park, NC)] was applied to the soil at the base of plants immediately after transplanting for control of spotted cucumber beetle (Diabrotica undecimpunctata) and squash bug (Anasa tristis). The herbicide halosulfuron-methyl [0.56 oz/acre a.i. (Sandea; Gowan Chemical, Yuma, AZ)] was applied to plots $\approx 2$ weeks after planting. Fungicides and insecticides were applied according to commercial recommendations for acorn squash grown in Kentucky (Coolong et al., 201la).

Automated irrigation was managed using paired-switching tensiometers (model RA 12-inch; Irrometer, Riverside, CA) following the method of Coolong et al., 2011b. In brief, one tensiometer functioned to turn on irrigation at the set point reflecting a higher (drier) soil moisture tension, whereas the other turned it off at the set point indicating the lower (wetter) soil moisture tension. Tensiometers were placed $\approx 8$ inches from the center of the bed (planted row) in line with a squash plant at a depth of 8 inches from the bed surface. The midpoint of the ceramic tip of the tensiometer was about the same depth as the drip tubing in the plant beds. Irrigation treatments had set points of on /off: $-40 /-10$ cbar and $-60 /-10$ cbar. These set points were reflective of irrigation being initiated when soil moisture levels reached $75 \%$ and $50 \%$ of PAW for the $-40 /-10$ cbar and $-60 /-10$ cbar treatments, respectively. The soil moisture tensions for this site that reflected $75 \%$ and $50 \%$ of PAW were determined based on soil moisture release curves developed for the site as well as soil water characteristic values developed by Saxton and Rawls (2006) for a silt loam soil. Predicted evapotranspiration (Et) values were also used to determine PAW settings. Predicted reference Et was calculated using the method of Hargreaves and Samani (1985), with crop coefficients for winter squash (Allen et al., 1998) used to estimate crop Et. Plants were watered equally for 1 week after transplanting at which time irrigation treatments were implemented. The frequency and duration of the automated irrigation events were recorded with data loggers (Hobo U9 State Data Logger; Onset, Cape Cod, MA). Average total water use for the season was calculated by multiplying the frequency and duration of irrigation events by the measured average flow rate at the beginning of the season 
in each plot at constant pressure (10 psi). Single-plot flow rates for the drip tubing were measured using a mechanical flow meter (DLJSJ50 Water Meter; Daniel L Jerman Co., Hackensack, $\mathrm{NJ}$ ) at the beginning and end of the experiment to determine if there was any impact of burying the drip tubing compared with SUR drip tape. In both seasons, there were no differences in flow rate between SUR and SDI and no difference between flow rates at the beginning and end of the study. Experimental units (plots) contained 24 plants each and were arranged in a two (SUR and SDI) by two ( $75 \%$ and $50 \%$ PAW) factorial randomized complete block design with four replications. Plots were $48 \mathrm{ft}$ long with beds 28 inches wide spaced on 6-ft centers. Because of the design of the irrigation system, all of the replicates in a given treatment were watered at the same time and therefore were not completely independent of each other. However, each plot was treated independently for the measurement of all yield and soil moisture parameters.

Soil moisture probes (Watermark, Irrometer) were placed at 3-, 6-, and 9-inch depths in the raised beds at the same relative location to plants as tensiometers. An access hole adjacent to the plant bed was dug and probes were placed in undisturbed soil in a parallel orientation with the bed surface. In 2011, data loggers were unavailable to record soil moisture readings. Daily measurements were taken with soil moisture probes and a handheld meter (Watermark Meter; Irrometer). However, single daily measurements were subject to excessive variability, and were provided an inadequate representation of soil moisture status. Therefore data loggers were employed in 2012. In 2012 , probes were connected to data loggers (Watermark 900M Monitor; Irrometer) and soil moisture (centibars) measured hourly throughout the study. Daily soil moisture tension averages were obtained from each depth for data analysis.

Harvests were conducted when fruit were mature on 9 Sept. 2011 and 28 Aug. 2012. Twenty plants in the center of each plot were harvested and fruit were graded into marketable and cull fruit based on U.S. Department of Agriculture (USDA) grade standards for fall and winter type squash and pumpkin (USDA, 1983). Average fruit size (width) was calculated based on the average of ten representative fruit per plot.

Weather data were obtained from an on-farm weather station that recorded environmental variables every minute and provided hourly averages [Kentucky Mesonet, Fayette County Station, Lexington, KY (University of Kentucky, 2015)]. Crop Et values were estimated using crop coefficients for winter squash and temperature values collected at the site (Allen et al., 1998; Hargreaves and Samani, 1985). Effective rainfall was estimated at each rain event and was calculated to be $\approx 80 \%$ of total rainfall for the season (Dastane, 1978). Because the four replicates within a treatment were irrigated at the same time, they were not considered completely independent. Therefore statistical analyses were conducted using Proc Mixed to account nonindependence of the replicates and covariance was estimated. Multiple comparisons procedures were carried out using Fisher's least significant difference with SAS statistical software (version 9.3; SAS Institute, Cary, NC).

\section{Results and discussion}

Weed pressure was visibly lower in SDI plots. Although weeds were regularly removed before causing competition with the crop, more weeds germinated in SUR plots compared with those with SDI. This difference was most visible in 2012 when rainfall was minimal and surface wetting from irrigation likely impacted weeds to a greater extent.

Air temperatures during the 2011 season were cooler and rainfall greater than in 2012. Daily average air temperatures were 75.9 and $77.4^{\circ} \mathrm{F}$ during the 2011 and 2012 studies, respectively. Average high air temperatures during the study periods were 84.7 and $88.0{ }^{\circ} \mathrm{F}$ in 2011 and 2012 , respectively. In 2011 , the research site experienced 10 inches of rain, whereas 7.0 inches were received in 2012 (Fig. $1)$. Rainfall in 2011 was greater during the initial 4 weeks and last week of the study. In 2012, rainfall was concentrated primarily during weeks 3-7 of the study. Periods of high rainfall generally corresponded to weeks when fewer irrigation events occurred (Fig. $2 \mathrm{~A}$ and $\mathrm{B}$ ). In 2011, irrigation events were concentrated during weeks 6 and 7 , which corresponded to a period of low rainfall. Similarly, irrigation frequency decreased notably in 2012 during week 6 , following a period of steady rain.

Average water applied ranged from 43,300 to $81,200 \mathrm{gal} /$ acre in 2011 (Table 1). In 2011, SDI treatments used less water than corresponding SUR treatments. The 75\% PAW SDI treatment used the least amount of water and had an average irrigation run time of $96 \mathrm{~min}$. The average run times for SUR plots were, 168 and $167 \mathrm{~min}$, for the $75 \%$ and 50\% PAW treatments, respectively. Despite similar irrigation run times, the $75 \%$ PAW SUR treatment irrigated more frequently in the first 4 weeks of the trial, resulting in greater water use for the study period (Fig. 2A). The $75 \%$ PAW SDI treatment in 2011 ran more frequently (14 events) and for a shorter average time period $(96 \mathrm{~min}$ ) compared with the 50\% PAW SDI treatment, which had nine irrigation events averaging $185 \mathrm{~min}$ each. The relatively longer average irrigation time for the $50 \%$ PAW SDI treatment resulted in greater water use during 2011 compared with the 75\% PAW SDI treatment, despite having fewer irrigation events.

In 2012 , more water was used by all treatments compared with 2011 . This was likely due to a lack of rainfall during the beginning and end of the study period in 2012 (Fig. 1). In 2012 , water use ranged from 90,900 to $170,000 \mathrm{gal} / \mathrm{acre}$ in the SUR $50 \%$ PAW and SDI 75\% PAW treatments, respectively. In contrast to 2011 , SDI treatments in 2012 applied more water than their SUR counterparts due to relatively long $(>4 \mathrm{~h})$ run times. In 2012 , the SUR $75 \%$ PAW treatment experienced the most irrigation events (48) and shortest average run time (92 min) of any treatment in this study. This irrigation pattern was reflective of a SUR-based irrigation system designed to maintain a relatively high level of soil moisture (Coolong et al., $2011 b$, 2012). Similarly, in 2011 , the SUR-based treatments were more frequently irrigated than corresponding SDI treatments. The SUR 75\% PAW treatment experienced 19 irrigation events in the final 2 weeks of the study in 2012, whereas other treatments had two or three irrigation events during the same time period (Fig. 2B). Although the SUR 75\% PAW treatment irrigated more frequently than other treatments, the irrigation events that occurred in the final 2 weeks of the 
experiment contributed disproportionately to the large difference in total irrigation events found in this treatment compared with the others.

Water use differed between SUR and SDI systems in 2011 and 2012. Zotarelli et al. (2009) discussed differences in emitter distance as a possible cause for a SDI system to use more water than a corresponding SUR soil moisture sensor-based irrigation system. Tensiometers and drip tape were placed in a similar manner in both years, although emitter distance relative to tensiometers in SDI treatments may have varied, as tape can stretch slightly during the laying process. However, differences in the weather conditions (rain and air temperature) also likely contributed to SUR-based treatments using less water than SDI in 2012. During the first 3 weeks of the study in 2012 , there was approximate rainfall of 1 inch (Fig. 1) and $8 \mathrm{~d}$ with high temperatures exceeding $100{ }^{\circ} \mathrm{F}$. During this time, average irrigation events for SDI treatments increased in duration, though not frequency, resulting in more water use than SUR treatments (Fig. 2B). This suggests that the hot and dry weather experienced in 2012 may have contributed to less efficient water applications by the SDI systems compared with SUR.

It should also be noted that the study period was $14 \mathrm{~d}$ longer in 2012 than in 2011, which may have contributed to some, though not all of the increased water use in 2012. The longer growing season encountered in 2012 may have been the result of an earlier transplant date coupled with hotter and drier growing conditions, which led to greater plant growth. In 2011 , average daily water

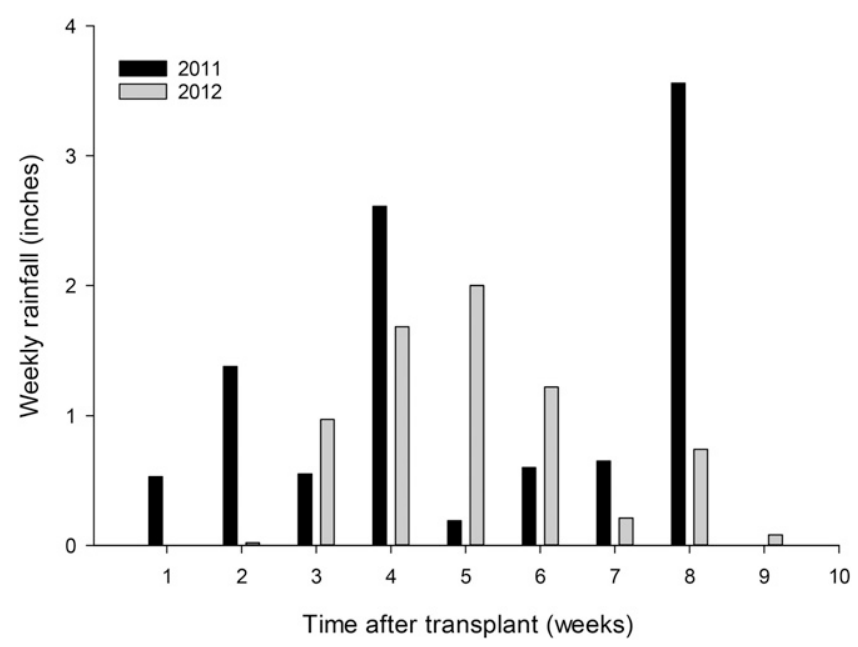

Fig. 1. Weekly total rainfall during the study period in 2011 and 2012 for 'Table Queen' acorn squash grown using surface and subsurface drip irrigation; 1 inch $=2.54 \mathrm{~cm}$.

use ranged from 790 to $1480 \mathrm{gal} /$ acre in the SDI and SUR 75\% PAW treatments, respectively (Table 1 ). In 2012 , average daily water use ranged from 1320 to $2460 \mathrm{gal} /$ acre in the SUR 50\% PAW and SDI 75\% PAW treatments, respectively. Although the study was conducted for a longer period of time in 2012 , average daily water use was still greater within all treatments in 2012 than in 2011, which was reflective of the drier and hotter conditions occurring in 2012.

Using crop Et values and estimated effective rainfall, the predicted total irrigation requirement for the study in 2011 was $93,000 \mathrm{gal} / \mathrm{acre}$. All treatments applied less water than this prediction. The SUR 75\% PAW treatment applied 81,200 gal/acre, which was closest to estimated required irrigation. In 2012, the estimated total irrigation requirement was $168,900 \mathrm{gal} / \mathrm{acre}$. The SDI $75 \%$ PAW treatment was most similar to estimated irrigation needs, applying $170,000 \mathrm{gal} /$ acre for the season. Interestingly, in both years, the volume of water used in a 75\% PAW treatment was most similar to that estimated to be required for irrigating this crop to account for rainfall and meet Et needs. However, the highest yielding treatments in 2011 (SDI 75\% PAW) and 2012 (SUR 75\% PAW) used $\approx 53 \%$ and $16 \%$ less water than was predicted to be necessary for irrigation. This suggests that soil moisturebased irrigation may be more efficient than solely using predictive Et-based methods (De Pascale et al., 2011), particularly when weather conditions are cool and wet, as occurred in 2011.

Soil moisture levels were affected by irrigation treatments in

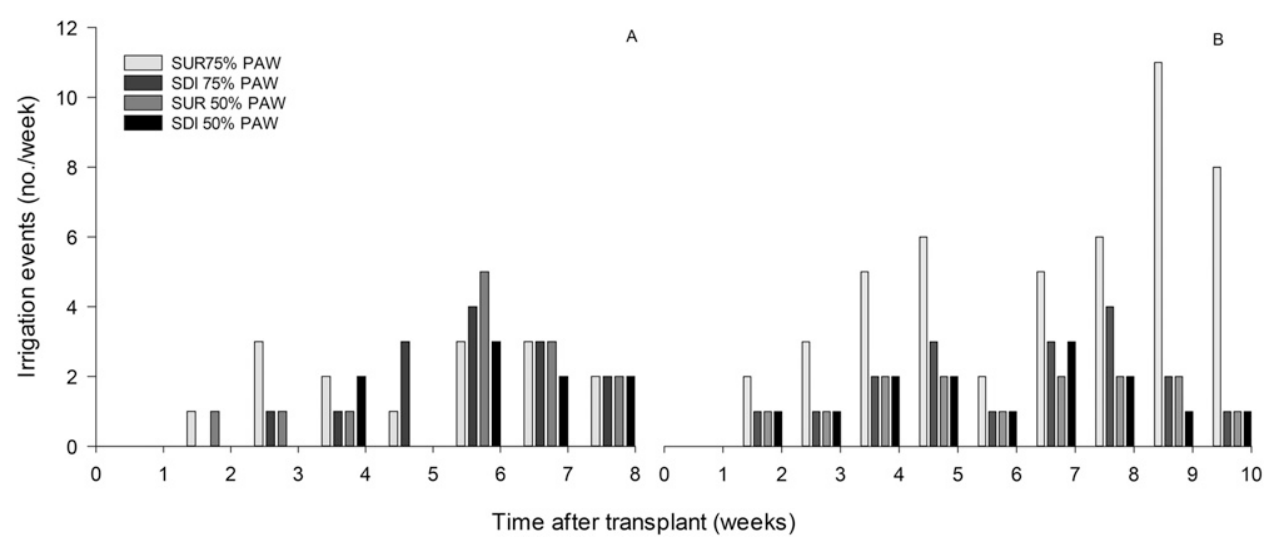

Fig. 2. Total number of weekly irrigation events in (A) 2011 and (B) 2012 for surface (SUR) and shallow subsurface drip irrigation (SDI) at set points of $75 \%$ and $50 \%$ plant available water (PAW) for the production of 'Table Queen' acorn squash. 
Table 1. Number of irrigation events, irrigation time per event, irrigation volume for the growing season, and average daily water use for 'Table Queen' acorn squash grown under surface (SUR) and subsurface drip irrigation (SDI) regimes in 2011 and 2012.

\begin{tabular}{|c|c|c|c|c|c|c|c|c|c|}
\hline \multirow[b]{2}{*}{$\begin{array}{l}\text { Irrigation } \\
\text { type }\end{array}$} & \multirow[b]{2}{*}{$\begin{array}{l}\text { Irrigation } \\
\text { setting } \\
(\% \text { PAW })^{z}\end{array}$} & \multicolumn{4}{|c|}{2011} & \multicolumn{4}{|c|}{2012} \\
\hline & & $\begin{array}{l}\text { Events } \\
\text { (no.) }\end{array}$ & $\begin{array}{c}\text { Irrigation } \\
\text { time (min) }\end{array}$ & $\begin{array}{c}\text { Irrigation } \\
\text { vol }(\text { gal/acre) }\end{array}$ & $\begin{array}{c}\text { Daily water } \\
\text { use (gal/acre } \\
\text { per day) }\end{array}$ & $\begin{array}{l}\text { Events } \\
\text { (no.) }\end{array}$ & $\begin{array}{c}\text { Irrigation } \\
\text { time } \\
(\mathrm{min})\end{array}$ & $\begin{array}{c}\text { Irrigation } \\
\text { vol (gal/acre) }\end{array}$ & $\begin{array}{c}\text { Daily water } \\
\text { use (gal/acre } \\
\text { per day) }\end{array}$ \\
\hline SUR & 75 & 15 & 168 & 81,200 & 1,480 & 48 & 92 & 142,200 & 2,060 \\
\hline SDI & 75 & 14 & 96 & 43,300 & 790 & 18 & 276 & 170,000 & 2,460 \\
\hline SUR & 50 & 13 & 167 & 69,900 & 1,270 & 14 & 201 & 90,900 & 1,320 \\
\hline
\end{tabular}

${ }^{2} \mathrm{PAW}=$ plant available water

${ }^{\mathrm{y}} \mathrm{l} \mathrm{gal} /$ acre $=9.3540 \mathrm{~L} \cdot \mathrm{ha}^{-1}$.

2012 (Table 2). The SUR 50\% PAW treatment had the highest soil moisture tension readings at every depth measured. This may be expected as it used the least amount of water of any treatment. There was also a significant interaction $(P<0.05)$ between depth and irrigation treatment for soil moisture tension. This was due to the SDI $50 \%$ PAW treatment having a higher soil moisture tension than the SDI $75 \%$ PAW treatment at a depth of 3 inches, but no difference in soil moisture tension between the two treatments at a depth of 9 inches. For a given irrigation level, soil moisture levels in SDI plots were generally greater than in SUR plots. Soil moisture tension values were reflective of the volumes of water applied. This suggests that despite the replicates of a given treatment being watered at the same time, irrigation regimes were accurately implemented. As expected, when main effects of sensor depth were evaluated, soil moisture tension increased significantly as sensor depth decreased (data not shown).

In 2011, both SDI treatments used less water than comparable SUR treatments, while maintaining numerically greater though not statistically different yields. In 2011, the SDI 75\% PAW treatment had an iWUE expressed on a dry weight basis of $0.066 \mathrm{lb} / \mathrm{gal}$ (Table 3 ). This was greater than all other treatments due to a slightly higher yield and lower water use. The SDI 50\% PAW treatment had the next largest iWUE at $0.047 \mathrm{lb} / \mathrm{gal}$. Both SUR treatments had iWUEs that were lower than SDI treatments in 2011. In 2012, however, the SDI 75\% PAW treatment had the lowest iWUE, producing $0.016 \mathrm{lb} / \mathrm{gal}$. This was lower than all other irrigation treatments in 2012 ,

Table 2. Soil moisture tension measured at depths of 3,6, and 9 inches for 'Table Queen' acorn squash grown under surface (SUR) and subsurface drip irrigation (SDI) regimes in 2012.

\begin{tabular}{lcccc}
\hline & & \multicolumn{3}{c}{ Soil moisture tension (cbar) $^{\mathrm{y}}$} \\
\cline { 3 - 5 } Irrigation type & $\begin{array}{c}\text { Irrigation } \\
\text { setting (\% PAW) }\end{array}$ & $\mathbf{3}$ & $\mathbf{6}$ & $\mathbf{9}$ \\
\cline { 3 - 5 } Septh (inches) & $\mathbf{6}$ \\
SUR & 75 & $23.9 \mathrm{~b}^{\mathrm{x}}$ & $23.1 \mathrm{~b}$ & $17.9 \mathrm{~b}$ \\
SDI & 75 & $17.9 \mathrm{c}$ & $16.4 \mathrm{c}$ & $14.7 \mathrm{~b}$ \\
SUR & 50 & $33.1 \mathrm{a}$ & $28.8 \mathrm{a}$ & $30.2 \mathrm{a}$ \\
SDI & 50 & $26.0 \mathrm{~b}$ & $21.1 \mathrm{bc}$ & $17.9 \mathrm{~b}$ \\
\hline
\end{tabular}

${ }^{2} \mathrm{PAW}=$ plant available water.

${ }^{y} \mathrm{l}$ cbar $=1 \mathrm{kPa}, 1$ inch $=2.54 \mathrm{~cm}$.

'Values in the same column followed by the same letter are not significantly different at $P \leq 0.05$ according to Fisher's least significant difference test.

Table 3. Irrigation water use efficiency expressed on a dry weight basis for 'Table Queen' acorn squash grown with surface (SUR) and subsurface drip irrigation (SDI) using a tensiometer-based control system in 2011 and 2012.

\begin{tabular}{|c|c|c|c|}
\hline \multirow[b]{2}{*}{ Irrigation type } & \multirow[b]{2}{*}{ Irrigation setting $(\% \mathrm{PAW})^{\mathrm{z}}$} & \multicolumn{2}{|c|}{ Water use efficiency $(\mathrm{lb} / \mathrm{gal})^{\mathrm{y}}$} \\
\hline & & 2011 & 2012 \\
\hline SUR & 75 & $0.030 c^{x}$ & $0.026 \mathrm{a}$ \\
\hline SDI & 75 & $0.066 \mathrm{a}$ & $0.016 \mathrm{~b}$ \\
\hline SUR & 50 & $0.032 \mathrm{c}$ & $0.028 \mathrm{a}$ \\
\hline SDI & 50 & $0.047 \mathrm{~b}$ & $0.026 \mathrm{a}$ \\
\hline & Year & & \\
\hline & 2011 & $0.043 \mathrm{a}$ & \\
\hline & 2012 & $0.024 \mathrm{~b}$ & \\
\hline
\end{tabular}

${ }^{\mathrm{z}} \mathrm{PAW}=$ plant available water

$\mathrm{y} 1 \mathrm{lb} / \mathrm{gal}=0.1198 \mathrm{~kg} \cdot \mathrm{L}^{-1}$.

${ }^{x}$ Values in the same column and year followed by the same letter are not significantly different at $P \leq 0.05$ according to Fisher's least significant difference test.

and less than one-quarter of the value of the same treatment in 2011 . Although yields were comparable between the SDI 75\% PAW treatments in both years, the volume of water used in that treatment increased roughly 4 -fold in 2012. This was due to an increase in average irrigation event time from $96 \mathrm{~min}$ in $201 \mathrm{l}$, to $276 \mathrm{~min}$ in 2012 . The other three irrigation treatments in 2012 had similar iWUEs, ranging from 0.026 to $0.028 \mathrm{lb} / \mathrm{gal}$. Dry surrounding soils and a high crop Et in 2012 may have caused the soil moisture-based
SDI system to respond differently than in 2011. Although SDI has often been shown to have a greater iWUE than SUR, our results are not unusual. AlOmran et al. (2005) reported variability in iWUE values for SUR and SDIgrown squash in a 2 -year study on sandy soils. Furthermore, although not statistically significant, Leskovar et al. (2001) reported that SURirrigated cantaloupe had a numerically greater iWUE during a hot and dry season, whereas fruit grown using SDI had a greater iWUE during a cool and wet growing season. 
When adjusted for fresh weight, the iWUE values in this trial are similar to those reported by Zotarelli et al. (2008) for zucchini squash.

There was a significant main effect of year on iWUE. Although yields were significantly lower in 2011, iWUE was greater, due to lower water use (Table 3). Interestingly, iWUE values for SUR treatments were similar in 2011 and 2012, ranging from 0.026 to $0.032 \mathrm{lb} /$ gal. However, there was variability in iWUE values for SDI treatments between years, with iWUE for SDI treatments decreasing by $44 \%$ and $76 \%$ for the $50 \%$ and $75 \%$ PAW SDI treatments, respectively. This suggests that environmental conditions may have a larger impact on a soil moisture-based SDI system compared with a SUR system.

Total marketable yield (weight) was not significantly affected by any treatment in 2011 (Table 4). However, numbers of fruit harvested were affected by treatment. The SDI $75 \%$ PAW treatment had the greatest number of fruit $(15,340$ fruit/acre), which differed from the SUR 50\% PAW (11,970 fruit/acre) treatment. Interestingly, the treatment that used the least amount of water in 2011 yielded the largest number of fruit. This was likely due to the greater rainfall in 2011 compared with 2012 , reducing the impact of irrigation during flowering and fruit set. The percentage of cull fruit and average fruit weight were unaffected by treatment in 2011 . Average fruit diameter, which is important in the wholesale marketing of acorn squash, was greatest in the SDI 50\% PAW treatment and lowest in the SUR 75\% PAW treatment.

In 2012, fruit weight and number were affected by irrigation treatment. The SUR 75\% PAW treatment had the greatest yield with $20,930 \mathrm{lb} /$ acre and 18,620 fruit/acre. This treatment had the most irrigation events of all treatments. Interestingly, a large number of irrigation events (19) occurred in the SUR 75\% during weeks 9 and 10 of the trial compared with other treatments. By this time, the number of fruit on each plant had already been established. Because average fruit weight did not differ among treatments in 2012 , it is likely that the irrigation events that occurred during the initial weeks of the study had a greater impact on yield than those late in the season. Sharma et al.

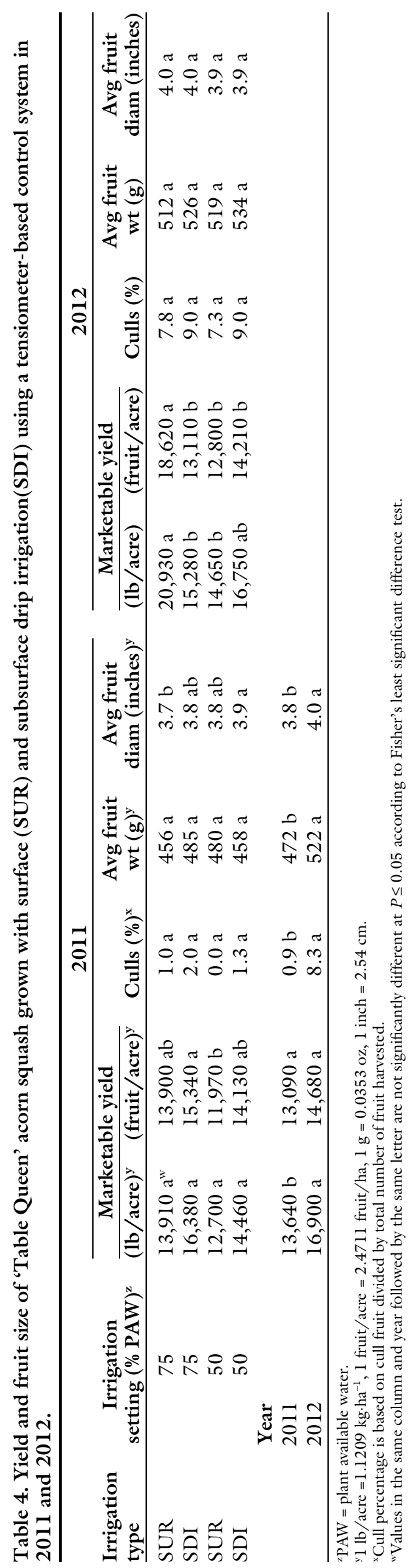


(2014) reported increases in yields of SDI-grown cantaloupe grown at $100 \%$ Et compared with $50 \% \mathrm{Et}$, due to increases in fruit number in a drier season and due to increases in fruit size in a wetter season. By wetting the soil surface more frequently early in the study, when temperatures were high and rainfall minimal, the $75 \%$ SUR irrigation treatments promoted more vigorous growth leading to plants with the ability to set more fruit, resulting in higher yields. Similarly, Leskovar et al. (2001) noted that early irrigations from SUR or very shallow SDI $(10 \mathrm{~cm})$ were more effective in wetting the root zone and enhancing early plant growth leading to earlier and larger yields compared with SDI at depths of $30 \mathrm{~cm}$. Because of high rainfall and cooler temperatures during plant establishment in 2011 , the effects of SDI and SUR on yield may have been reduced. The rate of cull fruit and fruit diameter were unaffected by irrigation treatment in 2012 .

There were significant main effects of year on yield. In 2012, average yield (weight) was greater than in 2011 , although the average number of fruit harvested did not differ between the two trial years. Average fruit weight and diameter were greater in 2012 than in 2011 (Table 4). The percentages of culls were lower in 2011 compared with 2012 . The yield increase in the SUR 75\% PAW treatment in 2012 was likely the reason for the overall higher yields for 2012, as the other treatments differed little between the study years. Yields in both years were greater than reported in other trials for the region (Spalding and Coolong, 2010).

\section{Conclusions}

Permanent and single-use SDI have been reported to have several advantages over traditional SUR (Ayars et al., 2015; Camp, 1998; Lamm and Camp, 2007). In this study, results comparing SDI and SUR were variable when considering water use and yield. In 2011, SDI used less water than corresponding SUR treatments while producing similar yields. In 2012, the SUR treatments used less water while yielding the same or more than corresponding SDI treatments. Frequent wetting of the soil surface in the $75 \%$ PAW SUR treatment during the first several weeks of the trial in 2012 may have led to improved plant establishment and greater yields in that treatment, while using less water than the comparable SDI treatment. During 2011, the iWUEs of both SDI treatments were greater than SUR, suggesting that SDI has the potential to increase iWUE to greater levels than SUR irrigation under some environmental conditions. However, differences in soil moisture sensor placement or settings for automated control of SDI compared with SUR irrigation may be required to fully use the potential of SDI in soil moisturebased irrigation systems.

\section{Literature cited}

Allen, R.G., L.S. Pereira, D. Raes, and M. Smith. 1998. Crop evapotranspiration: Guidelines for computing crop water requirements. FAO Irr. Drainage Paper No. 56. Food and Agricultural Organization, Rome, Italy.

Al-Omran, A.M., A.S. Sjeta, A.M. Falatah, and A.R. Al-Harbi. 2005. Effect of drip irrigation on squash (Cucurbita pepo) yield and water-use efficiency in sandy calcareous soils amended with clay deposits. Agr. Water Mgt. 73:43-55.

Ayars, J.E., A. Fulton, and B. Taylor. 2015. Subsurface drip irrigation in California: Here to stay? Agr. Water Mgt. 157: 39-47.

Ayars, J.E., C.J. Phene, R.B. Humacher, K.R. Davis, R.A. Schonemann, S.S. Vail, and R.M. Mead. 1999. Subsurface drip irrigation of row crops: A review of 15 years of research at the Water Management Research Laboratory. Agr. Water Mgt. 42:1-27.

Camp, C.R. 1998. Subsurface drip irrigation: A review. Trans. Amer. Soc. Agr. Eng. 41:1353-1367.

Coolong, T. 2013. Using irrigation to manage weeds: A focus on drip irrigation, p. 161-179. In: S. Soloneski and M. Larramendy (eds.). Weed and pest control: Conventional and new challenges. Intech, Rijeka, Croatia.

Coolong, T., R. Bessin, K. Seebold, J. Strang, and S. Wright. 201la. Vegetable production guide for commercial growers 2012-13. Univ. Kentucky Coop. Ext. Serv. Bul. ID-36.

Coolong, T., J. Snyder, R. Warner, J. Strang, and S. Surendran. 2012. The relationship between soil water potential, environmental factors, and plant moisture status for poblano pepper grown using tensiometer-scheduled irrigation. Intl. J. Veg. Sci. 18:137-152.
Coolong, T., S. Surendran, and R. Warner. 2011 b. Evaluation of irrigation threshold and duration for tomato grown in a silt loam soil. HortTechnology 21:466-473.

Dabach, S.U.S. and N. Lazarovith. 2015. Optimal tensiometer placement for highfrequency subsurface drip irrigation management in heterogeneous soils. Agr. Water Mgt. 152:91-98.

Dastane, N.G. 1978. Effective rainfall in irrigated agriculture. FAO Irr. Drainage Paper No. 25. Food and Agricultural Organization, Rome, Italy.

De Pascale, S., L.D. Costa, S. Vallone, G. Barbieri, and A. Maggio. 2011. Increasing water use efficiency in vegetable crop production: From plant to irrigation systems efficiency. HortTechnology 21:301-308.

Enciso, J., J. Jifon, and B. Wiedenfeld. 2007. Subsurface drip irrigation of onions: Effects of drip tape emitter spacing on yield and quality. Agr. Water Mgt. 92:126-130.

Grattan, S.R., L.J. Schwankl, and W.T. Lanini. 1988. Weed control by subsurface drip irrigation. Calif. Agr. 42(3):22-24.

Hargreaves, G.H. and Z.A. Samani. 1985. Reference crop evapotranspiration from temperature. Appl. Eng. Agr. 1:96-99.

Kong, Q., G. Li, Y. Wang, and H. Huo. 2012. Bell pepper response to surface and subsurface drip irrigation under different fertigation levels. Irrig. Sci. 30:233-245.

Lamm, F.R. and C.R. Camp. 2007. Subsurface drip irrigation, p. 473-551. In: F.R. Lamm, J.E. Ayars, and F.S. Nakayama (eds.). Microirrigation for crop production. Elsevier, Amsterdam, The Netherlands.

Leskovar, D.I., J.C. Ward, R.W. Sprague, and A. Meiri. 2001. Yield, quality, and water use efficiency of muskmelon are affected by irrigation and transplanting versus direct seeding. HortScience 36:286-291.

Leskovar, D.I., K. Kolenda, K.S. Yoo, and L.M. Pike. 2004. Containerized transplants and subsurface drip improved yield and quality of short-day onions. Acta Hort. 631:155-160.

Maynard, D.N. and G.J. Hochmuth. 2007. Knott's handbook for vegetable growers. 5 th ed. Wiley, Hoboken, NJ.

Patel, N. and T.B.S. Rajput. 2007. Effect of drip tape placement depth and irrigation level on yield of potato. Agr. Water Mgt. 88:209-223.

Saxton, K.E. and W.J. Rawls. 2006. Soil water characteristic estimates by texture and organic matter for hydrologic solutions. Soil Sci. Soc. Amer. J. 70:1569-1578.

Sharma, S.P., D.I. Leskovar, K.M. Crosby, A. Volder, and A.M.H. Ibrahim. 
2014. Root growth, yield, and fruit quality responses of reticulatus and indorus melons (Cucumis melo L.) to deficit subsurface drip irrigation. Agr. Water Mgt. 136:75-85.

Smajstrla, A.G. and S.J. Locascio. 1996. Tensiometer-controlled, drip-irrigation scheduling of tomato. Appl. Eng. Agr. 12:315-319.

Spalding, D. and T. Coolong. 2010. Acorn and butternut squash cultivar trial. 2010 Fruit and vegetable research report. Univ. Kentucky Coop. Ext. Serv. Bul. PR-608.
University of Kentucky. 2015. Lexington, Kentucky climate data. 6 June 2015. <http://wwwagwx.ca.uky.edu/cgi-bin/ ky_clim_data_www.pl>.

U.S. Department of Agriculture (USDA). 1983. United States standards for grades of fall and winter type squash and pumpkin. U.S. Dept. Agr., Washington, D.C.

Woodrow, J.E., J.N. Seiber, J.S. Lenoir, and R.I. Krieger. 2008. Determination of methyl isothiocyanate in air downwind of fields treated with metam-sodium by subsurface drip irrigation. J. Agr. Food Chem. 56:7373-7378.
Zotarelli, L., M.D. Dukes, J.M. Scholbert, T. Hanselman, K. LeFemminella, and R. Munoz-Carpena. 2008. Nitrogen and water use efficiency of zucchini squash for a plastic mulch system on a sandy soil. Scientia Hort. 116:8-16.

Zotarelli, L., J.M. Scholberg, M.D. Dukes, R. Munoz-Carpena, and J. Icerman. 2009. Tomato yield, biomass accumulation, root distribution and irrigation water use efficiency on a sandy soil, as affected by nitrogen rate and irrigation scheduling. Agr. Water Mgt. 96:23-34. 